\title{
APPLICATION OF REVISED BLOOM'S TAXONOMY IN THE BRANCH OF TOURISM
}

\section{APLIKACE REVIDOVANÉ BLOOMOVY TAXONOMIE V OBORU CESTOVNÍ RUCH}

\author{
Mgr. TAşÁnA KARÁSKOVÁ, M. A. \\ Katedra cestovního ruchu $\mid$ Department of Tourism \\ Obchodn Пpodnikatelská fakulta v Karviné School of Business Administration in Karvina \\ Slezská univerzita v Opav $\mid$ Silesian University in Opava \\ $\bowtie$ Univerzitní nám П̦tí 1934/3, 73340 Karviná, Czech Republic \\ E-mail: karaskova@opf.slu.cz
}

\begin{abstract}
Annotation
Commonly the human capital is defined as knowledge and skills which the person disposes of. The article concentrates on details on selected methods of education in the field of Tourism which are one of important elements of the intellectual capital. The aim of the article is to apply the knowledge of educational processes by means of the methodology of Bloomô taxonomy of cognitive objectives of practice in tourism. Presently when new curricula are prepared and new tools for verifying their completing revised taxonomy of educative objectives is already considered. In the educative process of study of tourism a new revised system has its justification and therefore it aspires to be used in the problems of tourism. The purpose of introduced problems of Bloomô taxonomy is to stimulate students to further cognition, searching solution, activating analytic and synthetic processes which consequently are applied into professional fulfilment.
\end{abstract}

\section{Key words}

tourism, cognitive processes, Bloomôs taxonomy

\section{Anotace}

Obecn \se lidský kapitál vymezuje jako znalosti a dovednosti, kterými jedinec disponuje. PŚisp円łek se

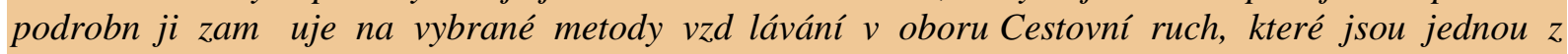

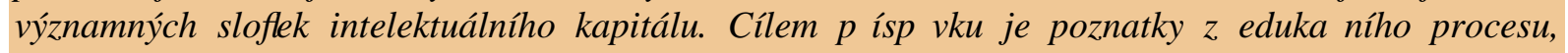
aplikovat prostSednictvím metodiky Bloomovy taxonomie kognitivních cílT do praxe v cestovním ruchu. $V$ sou! asnosti, kdy jsou pŚpravována nová kurikula a nové nástroje pro ovhśování jejich naplŔRování je jiǵ pŚihlíǵno k revidované taxonomii vzdநávacích cílT. Veduka! ním procesu studia cestovního ruchu má nov revidovaný systém své oprávn Đí a proto reflektuje na vyuğití $v$ problematice cestovního ruchu. Zám గerem nastolených problém $\mathrm{z}$ Bloomovy taxonomie je podnítit

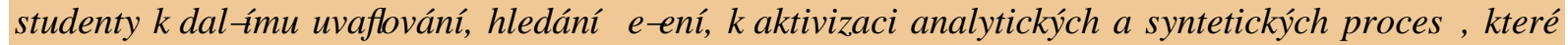
následn Пaplikuje do profesního uplatnПií.

\section{Klị́ ová slova}

cestovní ruch, kognitivní procesy, Bloomova taxonomie

\section{JEL classification: X12}

\section{Introduction}

The human capital is knowledge incorporated in people. It can be divided into knowledge (that is knowledge and information which the individual has and which is able to express and communicate in some way) and cognitive and also performance skills which are current capabilities of a particular 
person, and as such directly non-transferable (compare Veselý, 2006, s. 9). The human capital, however, is not only the result of education, but the whole scale of components and factors partake in it, which is formed in the course of the life of every individual. Professional education develops on the base of elementary education and in its beginnings it was conceived in a utilitarian way; originally general educational elements were totally suppressed. Education fulfilled the social dimension, as it was determined to physically working persons. By gradual modernisation of educational contents by scientific institutions with introducing the content into the accord with science it started the transformation from the static approach to the dynamic one.

\section{The capital as a concept of education}

The human capital can be understood as the productive abilities of a person that is what is invested into production. Thus understood human capital is indicated as the basic human capital. By its extension then so called broader human capital originates by which it is understood the potential to develop and to enforce own abilities. Many theories of study pay attention to gradual broadening knowledge, ways of interpretation and feedback, practising acquired knowledge and finally examination and evaluation of successfulness of workers in tourism. In the branch of tourism there is connected the theory (marketing, management, geo-marketing, guide activities, the theory of spa care, hotel services, as well as accounting, statistics and environmental management) and that all should be connected with practical examples and creativity of students. The target of the field of study is to teach students to study by innovative methods in the branch of tourism. In the field of pedagogy and psychology it is necessary to monitor various methods of learning in a comparative way, their successfulness at tuition, mainly in the branch of services. A special emphasis is necessary to be put on the way of education, the basic approach to the educational processes. These are the principles of so called ñ̉Bloomôs taxonomyñ

\section{Methods of educational processes}

Educational methods determine the way to fulfilling objectives of education. It is a coordinating system of the activity of the educationist and students, focused on achievement of knowledge in compliance with the beforehand set complex didactic rules.

There exists a wide scale of educational methods; some of them are similar to one another or they come out with references of one method from the other, other methods are significantly different and it is necessary to state that the universal and general educational method does not exist.

In the Czech Republic in the 70s professor L apek was inspired by Bloomô modified taxonomy, the work on classification of objectives of history teaching (1976, s. 71-90). The basic division of educational methods was also done by I. J. Lerner (1986) in the year 1986. His classification of educational methods comes out from the character of cognitive activities at acquirement of the content of the curriculum: the informative method with the broad adoption (clarifies, illustrates, the student perceives in a passive way, but perceptively):

- The informative receptive method

- The reproductive method ï the educationalist forms and presents tasks on reproducing knowledge and ways of an intellectual and practical activity, and students repeat the lectured knowledge.

- The method of problem explication (the educationalist forms the problem; in the dialogue with students the problem is solved).

- 4. The method of heuristic analysis (the educationalist clears up several compared problem phenomena and students themselves acquire new knowledge by a logical procedure).

- The scholastic, research method (students work independently by the specification and aspire to solve the set problem issue in a new way.

In their publication ñEducational methods ñ(2003) J. MaŔḱk and V. Ġvec use the combined point of view on educational methods, whereas they differentiate three groups, that is classical methods, activating methods and complex methods, and that is by the criterion of graded complexity of educational links. 


\section{How to teach - procedural approaches to education}

We come in to two specific problems. It is on one hand teaching of principles of the pedagogical process $\ddot{i}$ they are specifics of expertise of didactics. How to teach the process of learning itself? There arises another question how to teach tourism itself, often different from other specialisations. How can its teaching be done in the branch of services?

The plurality of procedures in the teaching process is obvious. There is another way of teaching mathematics, another way of teaching environmentalistics, or foreign languages and e.g. another way in teaching law aspects, or accountancy in tourism. Thus there is not a specific method of tuition of teaching which would be generally valid, sufficiently universal so that we could place it above all other methods. Every educational process has its specifics and it is necessary to select from pedagogical procedures those which are the most ideal. The correct definition of objectives and the educational activity of the teacher together with educational objectives in the activity of students can influence in its consequence a lot of development stimulating factors at education of students perspective orientation in the educational activity and educational auto regulation, the production of the appropriate aspiration level and adequate self-image and also disclosure of own possibilities of educational performances (Kurelová, 1999, s. 72).

\section{Bloomâ taxonomy}

Taxonomy of cognitive objectives (often called Bloomô taxonomy) was suggested in the year 1955 by the numerous team under leading of Benjamin Bloom, an educational psychologist at University in Chicago. The complex of educational objectives was divided into three areas of objectives: cognitive, affective and psychomotor, the criterion of this division comes out from relatively independent areas of psyche itself of educated subjects. In the real course of education all three mentioned features of psycho mingle mutually. It is taxonomy in the sphere of cognitive processes. It composes of six hierarchically organized categories of objectives which are further divided and are organized by the level of demandingness. As well as other taxonomies, Bloomôs one is constructed, which means that teaching on higher levels depends on the knowledge and abilities from lower levels. The advantage of Bloomôs taxonomy is to motivate a teacher and to concentrate on all three areas by creating more comparative forms of education.

In the year 2001 there was published the book Taxonomy for teaching and evaluating educational objectives which significantly revises the taxonomy of educational objectives worked out by $\mathrm{B}$. S. Bloom in the year 1956. The publication raised considerable attention in the professional sphere as Bloomôs taxonomy influenced for many years the creation of curricula and educational processes everywhere in the world. Not even our country was an exception (among others in the 70s professor L apek was inspired by Bloomô revised taxonomy to work on classification of objectives of history teaching). The publication in which the new theory was published is less known in our country in the meantime, it is known especially in the pedagogical sphere. In the meantime it is referred to mainly by pedagogy experts (Kotásek, Walterová) who draw the attention to the fundamental features of innovations.

\section{Why was Bloomôs theory innovated?}

Innovation of Bloomôs theory was preceded from several reasons:

1. Soon after publishing Bloomôs manual voices of scientists and also practical pedagogues started to be heard referring to some elements of the objective level which were not possible to be well monitored by Bloomô taxonomy. Neither Bloom nor his colleagues ever claimed the complexity of the taxonomy, they considered it as something very vivid which will be further made more precise and will be completed.

2. Since the year 1956 when Bloomô taxonomy was published there has been the development of cognitive psychology. By its development there were overcome some conclusions of behaviour psychology which Bloom took as the base. 
3. Despite the change of conditions which were made in education (the theory and practice as well) it was shown that the basic idea of taxonomy of objectives is not overcome, on the contrary developed educational systems use it more often, as there was generally accepted the idea that if the educational objectives are to be used in a meaningful way then it is necessary to classify them.

From these reasons in the 90s, when the further innovated publication of Bloom $\hat{\theta}$ manual was prepared by the publishing house Longman, David Krathwohl, one of the authors of the original manual, was asked to incorporate the results from the discussion and new scientific knowledge as well into the theory. From the discussion which was developed among workers from the publishing house and D. Krathwohl there was made an idea to modify of Bloomô original taxonomy. There was made a group of experts consisting of cognitive psychologists, theorists dealing with creation of curricula and specialists on testing and evaluation. The group worked on innovations from the year 1995 and in the year 1998 they presented a revised theory to the external opposition. After incorporation of suggestions the work was finished and published.

\section{Taxonomy of the cognitive process in the concept of tourism}

Bloom $\hat{Q}$ taxonomy is based on 6 hierarchically structured categories which are divided into subcategories. Bloom came out from the presumption that to reach a higher objective category it is necessary to master profoundly a lower category (consistency of objectives). Bloomô taxonomy is understood as specific rules for the area of educational processes, as they were set for the first time by Benjamin Bloom in the year 1955 at University in Chicago. The alternative category, expressing single cognitive processes, was modified by Anderson and Krathwohl (2001) and they state below examples of objectives, tasks and verbal links.

In the below stated revised Bloom $\hat{Q}$ taxonomy: By the dimensions of cognitive processes according to By! kovský and Kotásek (2004) it is aspired to apply the rule into the educational process: ñHow to teach the subject Tourism?ñ

Tab. 1: Dimension of the cognitive process in teaching

\begin{tabular}{|c|c|c|}
\hline $\begin{array}{c}\text { Category and } \\
\text { cognitive process }\end{array}$ & Alternative names & Definition and examples \\
\hline \multicolumn{3}{|c|}{ 1. To remember $\ddot{i}$ storing and recollecting knowledge from long-term memory } \\
\hline $\begin{array}{l}1.1 \text { Cognition and } \\
\text { recognition }\end{array}$ & $\begin{array}{l}\text { identifying, } \\
\text { defying, } \\
\text { structuring, } \\
\text { determining }\end{array}$ & $\begin{array}{l}\text { Questions of the type: } \tilde{r} \text { What is...? ñ Cognition of facts of } \\
\text { important facts in the sphere of hotel services, spa services and } \\
\text { tourism. To organize in the hierarchical sequence basic } \\
\text { knowledge on tourism. }\end{array}$ \\
\hline 1.2 Recollection & Re-recollection & $\begin{array}{l}\text { Recollection of facts of important events in the sphere of } \\
\text { tourism: in hotel services, spa services and tourism. }\end{array}$ \\
\hline \multicolumn{3}{|c|}{$\begin{array}{l}\text { 2. To understand } \ddot{i} \text { constructing the importance on the base of acquired statements, including oral, written or } \\
\text { graphic expressing. }\end{array}$} \\
\hline 2.1 Interpretation & $\begin{array}{l}\text { Explaining, } \\
\text { paraphrasing, } \\
\text { representing, } \\
\text { translating }\end{array}$ & $\begin{array}{l}\text { Questions of the type: } \tilde{\text { rH}} \text { How would you compare and } \\
\text { confront...? ñ Paraphrasing important speeches and documents } \\
\text { in the particular issue. }\end{array}$ \\
\hline 2.2 Exemplification & $\begin{array}{l}\text { illustrating, } \\
\text { installing }\end{array}$ & $\begin{array}{l}\text { Marking the observed or described phenomena in the sphere of } \\
\text { tourism, it is e.g. understanding mutual connections of singular } \\
\text { aspects, e.g. in the system HACCP in hotel chains and their } \\
\text { interpretation. }\end{array}$ \\
\hline 2.3 Classifying & $\begin{array}{l}\text { categorizing, } \\
\text { subordinating }\end{array}$ & $\begin{array}{l}\text { A student learns the teaching material, but he is not able to put it } \\
\text { in coherence. Mutual correlation of learned can be the starting } \\
\text { point. }\end{array}$ \\
\hline 2.4 Summarising & $\begin{array}{l}\text { generalising, } \\
\text { abstracting }\end{array}$ & $\begin{array}{l}\text { Abstracting the theme, e.g. description of a short summarisation } \\
\text { of organizational steps at realizing social events. }\end{array}$ \\
\hline
\end{tabular}




\begin{tabular}{|c|c|c|}
\hline $\begin{array}{c}\text { Category and } \\
\text { cognitive process }\end{array}$ & Alternative names & Definition and examples \\
\hline 2.5 Reasoning & $\begin{array}{l}\text { concluding, } \\
\text { predicting, } \\
\text { extrapolating, } \\
\text { interpolating } \\
\end{array}$ & $\begin{array}{l}\text { Derivation of the logical conclusion from presented information, } \\
\text { e.g. deduction of the rule of incorporating hotels into } \\
\text { categorisation and classification. }\end{array}$ \\
\hline 2.6 Comparing & $\begin{array}{l}\text { differentiating, } \\
\text { comparing, } \\
\text { connecting }\end{array}$ & $\begin{array}{l}\text { Finding out the relation between two ideas which are connected } \\
\text { together, or objects and their details, e.g. comparing sales in hotel } \\
\text { centres in time sequences. }\end{array}$ \\
\hline 2.7 Explaining & constructing models & $\begin{array}{l}\text { Creating the model of cause and consequence in the system (e.g. } \\
\text { clarification of causes of low sales in the relation to the } \\
\text { qualification level of employees). }\end{array}$ \\
\hline \multicolumn{3}{|c|}{ 3. Apply $\ddot{i}$ using the procedure or structure in various situations } \\
\hline 3.1. Performing & implementation & $\begin{array}{l}\text { Questions of the type: ñCan you classify for the } \\
\text { demonstration...? ñTo approach in an objective way to apply the } \\
\text { theory and practice. }\end{array}$ \\
\hline $\begin{array}{l}3.2 \text { Introducing } \\
\text { (implementation) }\end{array}$ & using & $\begin{array}{l}\text { Describe, apply the procedure on the unknown task, e.g. to } \\
\text { implement the innovated educational programme into practice of } \\
\text { the business of tourism. }\end{array}$ \\
\hline \multicolumn{3}{|c|}{$\begin{array}{l}\text { 4. Analyze } \ddot{i} \text { dividing the material into parts and determining what the mutual relation of the parts is and in } \\
\text { which relation they are to the total structure or the purpose. }\end{array}$} \\
\hline 4.1 Differentiation & \begin{tabular}{|l|} 
separating, \\
distinguishing, \\
concentrating, setting \\
apart
\end{tabular} & $\begin{array}{l}\text { The type of the question: } \tilde{\text { rD }} \text { istinguish ..... ñ Distinguishing } \\
\text { substantial and unsubstantial parts in the presented material, e.g. } \\
\text { to distinguish in the mathematical example substantial and } \\
\text { unsubstantial numbers. }\end{array}$ \\
\hline 4.2 Ordering & $\begin{array}{l}\text { Searching the accord } \\
\text { of integrating, } \\
\text { creating schemas, } \\
\text { structuring }\end{array}$ & $\begin{array}{l}\text { Questions of the type: ñHow would you insert...? } \\
\text { How would you insert innovation of the strategy of the enterprise } \\
\text { of tourism? }\end{array}$ \\
\hline 4.3. Attributing & detecting & 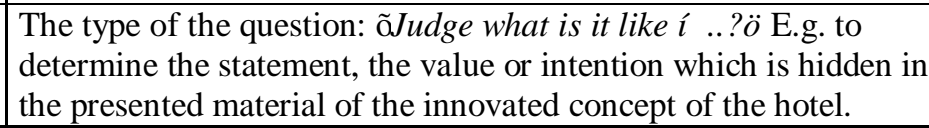 \\
\hline \multicolumn{3}{|c|}{ 5. Assess $\mathrm{i}$ assessment by given criteria and standards } \\
\hline 5.1 Monitoring & $\begin{array}{l}\text { coordinating, } \\
\text { detecting, monitoring, } \\
\text { testing }\end{array}$ & $\begin{array}{l}\text { Questions of the type: ñDo you agree with...? ñ Detection of } \\
\text { inconsistence or contradictions inside the process or the product, } \\
\text { determining whether the process or the product is internally } \\
\text { consistent, finding the efficiency of the process, how it was } \\
\text { introduced/implemented, e.g. to state whether scientific } \\
\text { conclusions respect the found out data. }\end{array}$ \\
\hline 5.2 Criticising & evaluating & $\begin{array}{l}\text { To find out inconsistence between the product and the outside } \\
\text { criteria, e.g. to judge which of two methods is better for solving } \\
\text { the given problem. }\end{array}$ \\
\hline \multicolumn{3}{|c|}{$\begin{array}{l}\text { 6. Create } \ddot{i} \text { creating new inner compound complexes from single elements, reorganizing elements into the new } \\
\text { sign or structure. }\end{array}$} \\
\hline 6.1 Creating & $\begin{array}{l}\text { formulation } \\
\text { hypotheses, } \\
\text { suggesting }\end{array}$ & $\begin{array}{l}\text { To suggest the educational programme for the small or middle- } \\
\text { size enterprise of tourism. }\end{array}$ \\
\hline 6.2 Planning & & $\begin{array}{l}\text { Planning methodology the educational programme for the small } \\
\text { or middle-size enterprise of tourism. }\end{array}$ \\
\hline 6.3 Creation & constructing & $\begin{array}{l}\text { Questions of the type: ACan you predict the resulté ?ñThe } \\
\text { proposal of the product, research of the particular issue, e.g. to } \\
\text { create entrepreneurial prospectus of the restaurant facility. }\end{array}$ \\
\hline
\end{tabular}

Source: BY L KOVSKÝ, P.; KOTÁSEK, J. Revize Bloomovy taxonomie edukal ních cílT, s. 227-242,Self processing, 2014.

Not always it is the application of Bloomô Taxonomy by itself in teaching tourism. It is mainly the fact how on the educational procedures of the systematic process of thinking to imprint into students the solution of a complex problem in services in spheres of tourism. 
The present development in the Czech Republic at the beginning of the century, being characterized by the epoch of globalisation of world economic and social processes, creates a strong pressure on the work capability practically in all categories of workers on various stages of management. On one hand the need of highly educated and qualified people with a certain size of personality and creativity is increasing; on the other hand the similar pressure is developed on the production of workers whose qualification and personality profiles will provide that they will perform quite simple work activities for a long term and in a routine way. This phenomenon is called polarisation of the working force and it is the base for the growth of importance of certain professional categories of workers (managers, designers, computer specialists, etc.), but also for increasing the group of people performing unskilled work.

In tourism there get ahead many trends and development tendencies which must be predicted and reflected by the educational system with the advance of several years, respectively by the change of competency of professionals in tourism. The objective of utilization of knowledge and orientation of their education is reaching the competence of graduates corresponding actual and future requirements required at the labour market.

Even from this reason the effort initiated to revive Bloomôs taxonomy and to adjust it considering the development and needs of practical innovations. Mentioned examples make the subject of meditation over the possibility to use revised Bloom $\hat{Q}$ taxonomy in professional preparation in the field of tourism. It is also probable that connections with this taxonomy, with defining educational objectives and respectively with other taxonomies of objectives will be the further search in other spheres of education.

\section{Literature}

[1] ANDERSON, L. W.; KRATHWOHL, D. R. (eds.), (2001a). A Taxonomy for Learning, Teaching, and Assessing: A Revision of Bloom' s Taxonomy of Educational Objectives. New York: Addison Wesley Longman. ISBN 0-321-08405-5.

[2] BLOOM, B., S., (ed.), (1956). . Taxonomy of Educational Objectives. The Classifications of Educational Goals. Handbook I: Cognitive Domain. New York: David McKey Company. ISBN 0-679-3029-3.

[3] Bloomrev [online]. [cit. 2014-04-13]. Dostupné z: http://coe.sdsu.edu/eet/ Articles /bloomrev /index.htm>.

[4] BYḶKOVSKÝ, P.; KOTÁSEK, J., (2004). Revize Bloomovy taxonomie edukal ních cílT. Pedagogika, vol. LIV, iss. 3, pp. 227-242.

[5] LLAPEK, V., (1976). Teoretické a metodologické základy didaktiky d円jepisu I. Praha: SPN.

[6] KALHOUS, Z., OBST, O. et. al., (2002). Ġolní didaktika. Praha: Portál. ISBN 80-7178-253-X.

[7] KURELOVÁ, M., et al., (1999). Pedagogika II. Kapitoly zobecné didaktiky. Ostrava: Ostravská univerzita. ISBN 80-7042-156-8.

[8] LERNER, I. J., (1986). Didaktické základy metod výuky. Praha: SPN.

[9] MAœé K, J., ǴVEC, V., (2003). Výukové metody. Brno: Paido. ISBN 80-7315-039-5.

[10] NH Revize Bloomovy taxonomie edukace [online]. [cit. 2014-04-13]. Dostupné z: <http://www.msmt.cz/files/doc/NHRevizeBloomovytaxonomieedukace.doc〉.

[11] OBST, O., (2006). Didaktika sekundárního vzdhávání. Olomouc: Univerzita Palackého. ISBN 80-244$1360-4$.

[12] Thinking/Blooms Tools [online]. [cit. 2014-04-13]. Dostupné z: <http://www.bssc. edu.au/public/learning teaching/ pd/toc/Blooms.shtml. Thinking/Blooms Tools>.

[13] VESELÝ, A., (2006). Teorie mnohal etných forem kapitálu. Praha: Univerzita Karlova. ISSN 1801-5999. [online]. [cit. 2014-04-22]. Dostupné z: 〈http://publication.fsv.cuni.cz/ attachments/117_014_Vesely.pdf〉.

The article was elaborated within the project Internal institutional project ISIP P 16 (Innovation of the Subject Gastronomy I - technology field of study Hospitality, study program Gastronomy, Hospitality and tourism for the year 2014) at Silesian University in Opava, School of Business Administration in Karvina. 